\title{
Capacitação de agentes comunitários de saúde em saúde auditiva: efetividade da videoconferência*****
}

\author{
Community health agents training on hearing health: effectiveness of \\ videoconference
}

Tatiana Mendes de Melo*

Kátia de Freitas Alvarenga**

Wanderléia Quinhoneiro Blasca***

Marcel Frederico de Lima Taga****

*Fonoaudióloga. Mestre em Fonoaudiologia pela Faculdade de Odontologia de Bauru - Universidade de São Paulo (FOB - USP). Professora do Curso de Fonoaudiologia da Universidade de Guarulhos. Endereço para correspondência: Rua Alto Garça, 1176 - Cidade Patriarca - SP CEP 03546-000 (tati_usp@yahoo.com.br).

**Fonoaudióloga. Livre-Docente pela FOB - USP. Professora Livre-Docente do Departamento de Fonoaudiologia da FOB - USP.

***Fonoaudióloga. Doutora em Distúrbios da Comunicação Humana pelo Hospital de Reabilitação de Anomalias Craniofaciais - USP. Professora Doutora do Departamento de Fonoaudiologia da FOB - USP.

****Matemático. Mestre em Estatística pela USP. Estatístico do Ministério do Desenvolvimento Social e Combate à Fome.

*****Trabalho Realizado no Departamento de Fonoaudiologia da FOB - USP.

Artigo Original de Pesquisa

Artigo Submetido a Avaliação por Pares

Conflito de Interesse: não

\begin{abstract}
Background: training of Community Health Agents on hearing health through videoconference. Aim: to verify the effectiveness of a training program for community health agents, through videoconference, on child hearing health. Method: participants of the study were 50 professionals who were randomly divided in two groups: 31 community health agents were physically present in the training program and 19 participated via videoconference. Training was provided in eight hours, through classes and using specific material adapted from the Primary ear and hearing care training resource - basic, intermediate and advanced levels for both groups, simultaneously. Training was organized and evaluated according to a previous study. Results: both groups presented a statistically significant difference when comparing pre and post training performances. However, for the group of community health agents who were physically present during the training program, this difference was higher not only when considering the final total scores but also when looking at the individual topics. Conclusion: videoconference was effective as a learning tool for the training of community health agents on child hearing health. However, this instrument should be used as a complementary material to the traditional form of training.
\end{abstract}

Key Words: Family Health Program; Hearing Loss; Training; Videoconference.

\section{Resumo}

Tema: capacitação de agentes comunitários de saúde na área de saúde auditiva por meio de videoconferência. Objetivo: avaliar a efetividade da capacitação dos agentes comunitários de saúde, por meio da videoconferência, na área de saúde auditiva infantil. Métodos: participaram da pesquisa 50 profissionais divididos aleatoriamente em dois grupos de acordo com a metodologia de ensino: 31 agentes comunitários de saúde participaram da capacitação de forma presencial e 19 por meio de videoconferência. A atividade ocorreu em um encontro de oito horas, por meio de aulas expositivas sobre o conteúdo ministrado e a utilização do material adaptado Primary ear and hearing care training resource - basic, intermediate and advanced levels, de forma simultânea para ambos os grupos. A capacitação foi organizada e avaliada de acordo com a proposta de estudo anterior. Resultados: ambos os grupos apresentaram diferença estatisticamente significante quando considerado o desempenho apresentado no instante pré e póscapacitação, de forma mais expressiva para o grupo que participou da capacitação de forma presencial, tanto na análise do escore total como quando considerado os temas abordados separadamente. Conclusão: a videoconferência como ferramenta de ensino foi efetiva para a capacitação dos agentes comunitários de saúde na área de saúde auditiva, porém deve ser utilizada de forma complementar à capacitação realizada de forma presencial.

Palavras-Chave: Programa Saúde da Família; Deficiência Auditiva; Capacitação; Videoconferência.

Recebido em 17.04.2009.

Revisado em 29.01.2010; 05.02.2010.

Aceito para Publicação em 22.04.2010. 


\section{Introduction}

In Brazil, the first Neonatal Hearing Screening Programs (NHS) began to appear in 1987. After almost two decades, Brazil already presents 237 NHS programs in 22 states 1 . However, this scenario does not reflect a wide access of Brazilian population to hearing impairment specialized service within the adequate period because: most of the programs are available in big cities and are carried out by private institutions; only a few NHS programs assure continuity in a reference and counter-reference system; even with an effective control it is not very common to reach $100 \%$ family involvement regarding either NHS accomplishment or process continuity; false-negative or falsepositive occurs in any of the procedures used; and acquired or late-onset hearing loss are not identified.

In this sense, the Family Health teams, after being trained on the hearing area, can not only work on promoting hearing health, but also on rescuing families that do not continue on the neonatal hearing screening and hearing diagnosis process, on identifying children with possible hearing function disorders and on guiding the family as regards the existence of treatment and the need to undertake it, which will help guarantee family's involvement in all stages of the process 2 .

Considering the amount of Family Health teams spread throughout the country, there arouse the need to make such distance training programs feasible. International experiences using videoconferencing as a teaching tool to train health agents in strategic/needy areas have showed significant success. 3-13

Therefore, the objective of this study was to evaluate the effectiveness of videoconferencing as a teaching tool for the training of community health agents (CHA) in infantile hearing health.

\section{Method}

The study was approved by the Human Research Ethics Committee of the School of Dentistry of Bauru - University of São Paulo (no007/ 2007) and authorized by the Department of Health of Bauru.

\section{Case Selection}

All the CHA of the city had no previous experience in hearing health and were invited to take part of the study. Only after having signed the Consent and Clear they were included in the case selection that was constituted by $50 \mathrm{CHA}$ from the Family Health teams coming from Santa Edwirges, Vila São Paulo and Jardim Godoy neighborhoods. The professionals were divided in two groups, i.e. 31 CHA were assigned to face-to-face training (control) and 19 to videoconferencing training, corresponding to total capacity of the room (study). The selection process was conducted at random, upon delivery of the graphic material.

\section{Equipment}

The equipment used for the videoconferencing training was a Polycom, model Viewstation 512, connected via Internet Protocol, and data transmission rate between 128 and $768 \mathrm{Kbp} / \mathrm{s}$, in both places. The other equipment used was a 32" television set, a multimedia projector, sound boxes and an additional camera that enabled the videoconferencing training group to follow-up the face-to-face training group.

\section{Procedures}

First, the participants were handed the training registration form that should be returned on the training day. This form included questions about age, education, parents' data and period of experience as a CHA and was filled out by the participants so the profile of the groups could be defined.

After returning this form, each participant received the training material and a numbered badge. Such procedure was adopted in order to keep the participants' identity confidential when the questionnaire was applied to evaluate the effectiveness of videoconferencing training, this way avoiding them embarrassment.

The courseware used was the World Health Organization (WHO) guide - Primary ear and hearing care training resource - basic, intermediate and advanced levels 14 , adapted and validated to Portuguese language 2. The use of this material allowed CHA to interactively follow the activities and also perform certain activities together with the facilitator.

Both training programs were carried out simultaneously in the School of Dentistry of Bauru in order to guarantee the same content was applied concomitantly to both groups of study.

The activity was part of the CHA daily routine of work, happened in an eight hour meeting and was developed through lectures with a break for questions and answers at the end. Such initiatives were grounded on relevant literature 15-16. 
A tutor was present in the distance training room to follow the training and transmit to the facilitators the questions made by the study group, besides providing the monitoring/feedback of the audio and video used. The presence of the tutor in the distance training room facilitates the learning process as regards continuing education of professionals through videoconferencing 6, 16-18.

Tools

In order do evaluate the effectiveness of videoconferencing as a teaching tool for the training of CHA in infantile hearing health, the same questionnaire was applied to both groups, pre and post training, according to procedure adopted in a study previously conducted 2 .

Analysis of the results

For the comparative analysis of both groups regarding the age and period of experience of the CHA, the Student's T test was used. For the comparison of the information about parenthood and neighborhood where CHA work, the chi-square and Fisher tests were used, respectively.

For the analysis of the performance of the CHA, both descriptive and inferentially, the total score of the 20 questions of the tool and the partial score of the questions of the pre and post training questionnaire were considered, relative to the domains described 2.

For the inferential analysis of the total score obtained from the questionnaire, an analysis of variance model with repeated measures on two factors was chosen: Type of qualification and Instant. For the comparison of the results in the different domains, the Wilcoxon test was used, with significance level at 5\%.

\section{Results}

In the face-to-face training group the CHA age ranged from 20 to 46 years (mean age 30 and standard deviation 7 years) and the work experience period with Family Health teams ranged from 1 to 72 months (mean period 23 and standard deviation 24 months). On the other hand, in the videoconferencing training group the CHA age ranged from 22 to 57 years (mean age 31 and standard deviation 8 years) and the work experience period with Family Health teams ranged from 1 to 60 months (mean period 21 and standard deviation 22 months). The CHA academic education was predominantly senior high school in both groups of study (26 CHA in the control group and 18 in the videoconferencing training group). All the other agents who received videoconferencing training reported junior high school. Additionally, in the control group there were three CHA with junior high school and two with college.

Both groups were compared using inferential statistics, considering the following variables: age, work experience period, parenthood and neighborhood were worked, and no difference statistically significant was observed between them ( $p=0,526, p=0,754, p=0,980, p=0,106$, respectively).

The descriptive analysis of the total score obtained from the pre and post training questionnaire (20 questions) as well as the difference obtained for both groups are represented in figure 1.

The inferential analysis of the total score shows the interaction factor between type of qualification and instant is significant $(\mathrm{p}<0.0035)$. Later, the Bonferroni correction was used for the comparisons post-hoc (Table 1).

At the pre qualification instant, the videoconferencing training group presented higher mean regarding overall hearing health knowledge when compared with face-to-face training group, with statistically significant difference $(\mathrm{p}<0.027)$. At the post qualification instant it was observed no difference statistically significant between the groups $(\mathrm{p}>1.0)$, showing that both groups presented similar learning level. Therefore, the improvement of the hearing health knowledge post qualification was more substantial in the face-toface group ( $\mathrm{p}<0.018)$.

For the results of the pre and post training questionnaires as regards the domains studies the inferential analysis was carried out, as shown on Table 2.

The face-to-face group kept the best learning, represented by the statistically significant difference of the score obtained for most of the domains, except for the overall aspects of the hearing impairment. On the other hand, in the group that received videoconferencing training the performance improvement was statistically significant only as regards prevention. 
FIGURE 1. Descriptive analysis of the groups studied according to total score and difference obtained from the pre and post training questionnaire.
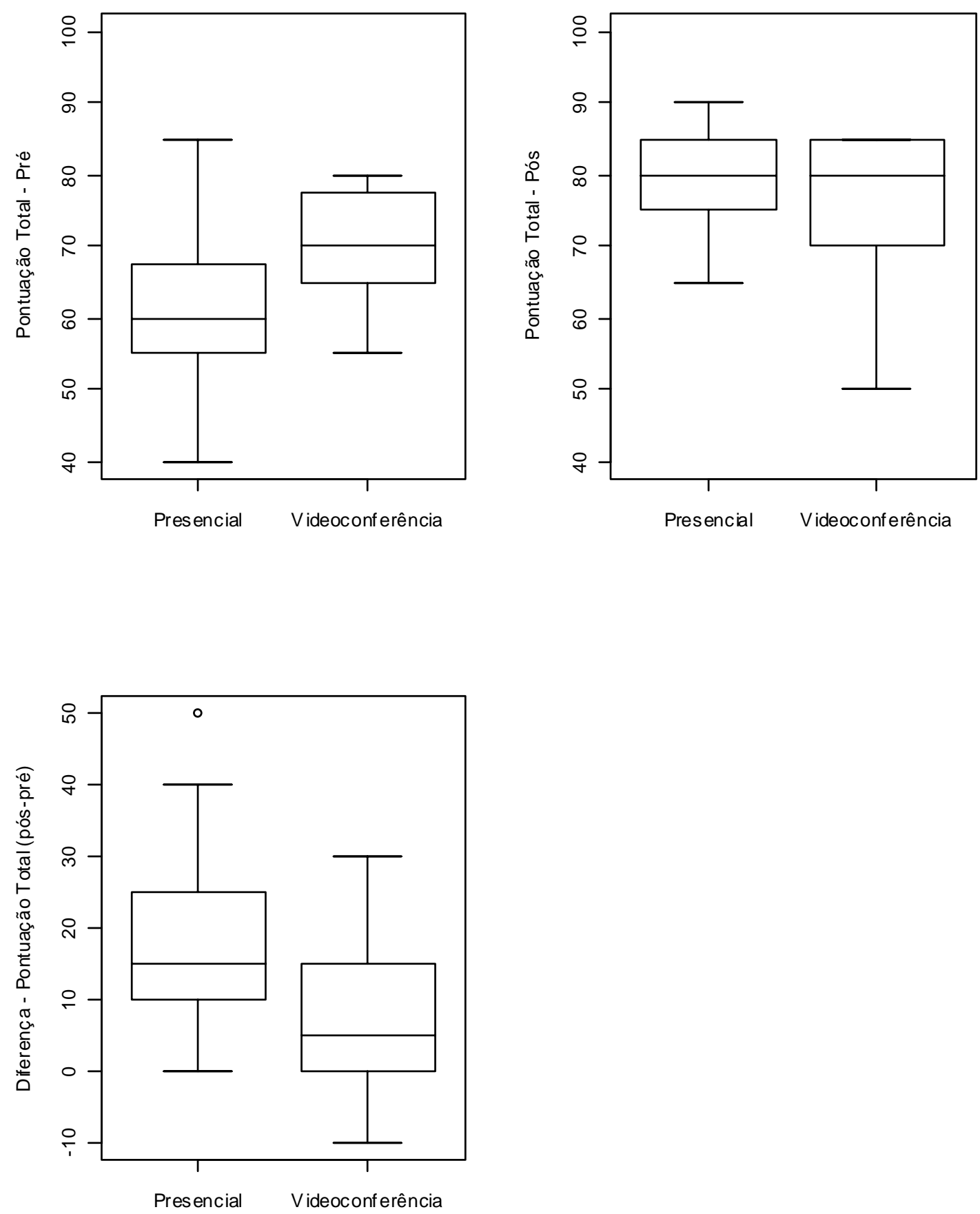
TABLE 1. Comparisons post hoc for the analysis of the kind of training programs used.

\begin{tabular}{|c|c|c|c|c|c|c|}
\hline \multirow{2}{*}{ Difference } & \multirow{2}{*}{ Forecast } & \multirow{2}{*}{$\begin{array}{c}\text { Standard } \\
\text { Error }\end{array}$} & \multirow{2}{*}{ gl } & \multirow{2}{*}{$\mathbf{p}^{*}$} & \multicolumn{2}{|c|}{$\begin{array}{c}\text { Confidence Interval } \\
(95 \%)^{*}\end{array}$} \\
\hline & & & & & $\begin{array}{c}\text { Lower } \\
\text { limit }\end{array}$ & $\begin{array}{r}\text { Higher } \\
\text { limit }\end{array}$ \\
\hline Dif Pre Face-to-face-Video & -8 & 2.7 & 90 & $0.027 *$ & -15 & -1 \\
\hline Dif Post Face-to-face-Video & 2 & 2.7 & 90 & 1.000 & -5 & 10 \\
\hline Dif Face-to-face Post-Pre & 17 & 2.0 & 48 & $0.001^{*}$ & 12 & 23 \\
\hline Dif Video Post-Pre & 7 & 2.6 & 48 & $0.044^{*}$ & 0 & 14 \\
\hline Dif (Face-to-face Post-Pre)-(Video Post-Pre) & 10 & 3.3 & 48 & $0.018^{*}$ & 1 & 19 \\
\hline
\end{tabular}

*Corrected by Bonferroni

${ }^{*}$ p ? 0.05: statistically significant

TABLE 2. Inferential analysis, by domains, obtained through face-to-face training and videoconferencing.

\begin{tabular}{ccc}
\hline Domains & Comparison & P \\
\hline \multirow{2}{*}{ Concepts } & Pre x Post (Face-to-face) & $0.001^{*}$ \\
& Pre x Post (Videoconferencing) & 0.059 \\
\hline Prevention & Pre x Post (Face-to-face) & $0.000^{*}$ \\
& Pre x Post (Videoconferencing) & $0.039^{*}$ \\
\hline Identification & Pre x Post (Face-to-face) & $0.000^{*}$ \\
\hline Overall aspects & Pre x Post (Videoconferencing) & 0.110 \\
\hline & Pre x Post (Face-to-face) & 0.078 \\
\hline
\end{tabular}

${ }^{*} p$ ? 0.05 statistically significant

\section{Discussion}

Since its start, the Family Health Strategy (FHS) has been expanding nationally, reaching in 2008 the significant figure of 28 thousand teams, present in $92 \%$ of the cities, and covering 87 million Brazilian people 19.
In this context, the challenge rests on providing balanced training programs for this high number of teams spread throughout the Brazilian regions. Therefore, it is necessary to leverage the connections in order to increase the offer of continuing education programs, thus being necessary to boost the acquisition of communication and information technologies. 
In 2006, the Ministry of Health, through Regulation 561/GM, created a Permanent Committee to develop cooperative works aiming the organization of continuing education process involving technological resources such as videoconferencing 20.

Therefore, this study is especially convenient, since it meets the current vision of the Ministry of Health that has increasingly taken steps to help the Family Health team to provide full and high quality assistance to the Brazilian population.

The results obtained show an improvement on CHA performance when answering the questions about the content taught, with statistically significant difference both for the face-to-face group ( $p<0.001)$ and for the videoconferencing group $(\mathrm{p}<0.044)$. The activity, regardless of the methodology used, was effective for knowledge acquisition of hearing health.

In both training programs, the objective was not only to teach the concepts, but also to set the scene for the CHA relating the concepts to their reality, allowing them to bring in the experiences they had with the community of their micro-area. Another important element was the organization of the activity that involved the correct choice of the contents, the use of the graphic material that was interactive and coherent with the contents taught in the training, the resource of the lectures divided in units with adequate break for questions, the use of images and videos to illustrate the concepts to be learned and the presence of the tutor in the continuing education training room all of which constituted elements that also probably contributed to the success of the activity 6-5, 15-18, 21.

However, the detailed analysis of the results allowed some relevant learning that must be taken into account when using videoconferencing for CHA training in infantile hearing health.

The professionals assigned to videoconferencing training started the program with a higher knowledge about hearing health. However, by the end of the program, they presented a similar performance to the group assigned to face-to-face program. Therefore, it is possible to note the learning of the content taught was less substantial for the CHA group assigned to videoconferencing training, $\mathrm{p}<0.018$.

The hearing health training included some contents that enable the CHA not only to work on the hearing health promotion, but also on identifying hearing loss and providing support to the family with a hearing impaired child by helping this family to enroll in the habilitation/rehabilitation program. In this context, an analysis was made considering the domains separately.

As described above, the face-to-face group kept the best learning, represented by the statistically significant difference in the score of the questionnaires for most of the domains, except for the overall aspects of the hearing impairment. On the other hand, in the group trained by videoconferencing the performance improvement was only statistically significant regarding prevention. Promotion and prevention of diseases are the main focus of the Family Health team in terms of basic attention to health. Therefore, the result presented by the group trained by videoconferencing is not surprising because probably the prevention of diseases might have been approached in other training situations and is rather linked to their work experience. Such previous knowledge may have facilitated the learning of hearing impairment prevention.

The results of this study show face-to-face learning program is still the most effective method. It is possible to assume in the face-to-face training program the control of the interaction among participants, as well as motivation, attention and interest, crucial conditions for the learning process, become more easily noticed and worked by the professional in charge of the training. Videoconferencing, on the other hand, may make it harder for the facilitator to get this feedback and consequently drive to a higher level of dispersion, even being the distance learning type of program most similar to the face-to-face training environment.

Regarding training effectiveness, there are other aspects besides performance pre and post training that may indicate the objectives were reached. The behavioral changes of CHA on their professional activity, i.e. bringing the theory into the actions they develop daily. The comment bellow illustrates CHA behavioral change:

(...)"This observation of the children's phases enables us to identify failures, difficulties that are sometimes unnoticeable for parents. It was very good because there was follow-up, we brought the knowledge acquired into our communities after the training. I count on you regarding issues, doubts that may arise to guarantee the continuity of the project."

\section{Conclusion}

Videoconferencing was an effective teaching tool for the continuing education process of the Family Health teams regarding hearing health. However, it must be used as a complement to the activities carried out by face-to-face qualification type of program in order to reach the results wanted. 


\section{References}

1. Chapchap MJ. Grupo de apoio de triagem auditiva neonatal universal - Quanto antes, melhor. Rev Fonoaud. 2005; 62:17-20.

2. Alvarenga KF; Bevilacqua MC; Martinez MANS; Melo TM; Blasca WQ; Taga MFL. Proposta para capacitação de agentes comunitários de saúde em saúde auditiva. Pro Fono. 2008;20(3):171-6.

3. Barden W, Clarke HM, Young NL, McKee N, Regehr G Effectiveness of Telehealth for Teaching Specialized Handassessment Techniques to Physical Therapists. Acad Med. 2000;75(10 Suppl):43-6.

4. Rees CS; Gillam D. Training in cognitive-behavioural therapy for mental health professionals: a pilot study of videoconferencing. J Telemed Telecare. 2001;7:300-3.

5. Haythornthwaite S. Videoconferencing training for those working with at-risk young people in rural areas of Western Australia. J Telemed Telecare. 2002;8(Supp 13):29-33.

6. Allen M, Sargeant J, Mann K, Fleming M, Premi J. Videoconferencing for practice-based small-group continuing medical education:feasibility, acceptability, effectiveness and cost. J Contin Educ Health Prof. 2003;23(1):38-47.

7. Loewen L, Seshia MMK, Askin DF, Cronin C, Roberts S. Effective delivery of neonatal stabilization education using videoconferencing in Manitoba. J Telemed Telecare. 2003;9:334-8.

8. Stain SC, Mitchell M, Belue R, Mosley V, Wherry S, Adams CZ et al. Objective assessment of videoconferenced lectures in a surgical clerkship. Am J Surgery. 2005;189:814

9. Karlinsky H, Dunn C, Clifford B, Atkins J, Pachev G, Cunningham $\mathrm{K}$ et al. Workplace injury management: using new technology to deliver and evaluate physician continuing medical education. J Occup Rehabil. 2006;16:719-30.

10. Metter DF, Woolley FR, Bradley Y, Morrison J, Phillips WT, Salman U et al. Teaching radiology residenct didactics using videoconferencing. Acad Radiol. 2006;13:1276-85.

11. Bednar ED, Hannum WM, Firestone A, Silveira AM, Cox TD, Proffit WR. Application of distance learning to interactive seminar instruction in orthodontic residency programs. Am J Orthod Dentofacial Orthop. 2007;132(5):586-94.
12. Bertsch TF, Callas PW, Rubin A, Caputo MP, Ricci MA. Effectiveness of lectures attended via interactive videoconferencing versus in-person in preparing third-year internal medicine clerkship students for clinical practice examinations. Teach Learn Med. 2007;19(1):4-8.

13. Rossaro L, Tran TP, Ransibrahmanakul K, Rainwater JA, Cski G, Cole SL et al. Hepatitis C videoconferencing: the impact on continuing medical education for rural healthcare providers. Telemed J E Health. 2007;13(3):26977.

14. World Health Organization: primary ear and hearing care training resource: basic, intermediate and advanced levels. [Acesso em 2006 ago 17]. Disponível em: http:// www.who.int/pbd/deafness/activities/hearing_care/en/ index.html.

15. Cruz DM, Barcia RM. Educação a distância por videoconferência. Tecnologia Educacional. 2000;150/ 151:3-10.

16. Bastos MAR, Guimarães EMP. Educação a distância na área da enfermagem: relato de uma experiência. Rev Lat Am Enfermagem. 2003;11(5):685-91.

17. Birden H, Page S. Teaching by videoconference: a commentary on best practice for rural education in health professionals. Rural Remote Health. 2005;5(2):356.

18. Moehr JR, Anglin CR, Schaafsma JP, Pantazi SV, Anglin S, Grimm NA. Videoconferencing based health: its implications for health promotion and health care. Methods Inf Med. 2005;44(2):334-41.

19. Brasil. Ministério da Saúde. Secretaria-Executiva. Mais saúde: direito de todos: 2008 - 2011. 2. ed. - Brasília: Editora do Ministério da Saúde; 2008. p. 100.

20. Brasil. Portaria $n^{\circ}$ 561, de 16 de março de 2006. Institui, no Âmbito do Ministério da Saúde, a Comissão Permanente de Telessaúde. Diário Oficial da União. 17 mar 2006; Seção $1: 59$

21. Motamedi V. A critical look at the use of videoconferencing in United States distance education. Education. 2001;122(2):386-94 